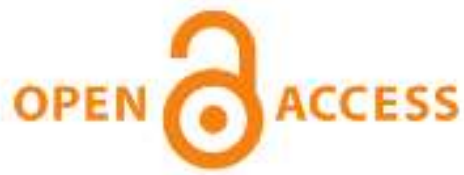

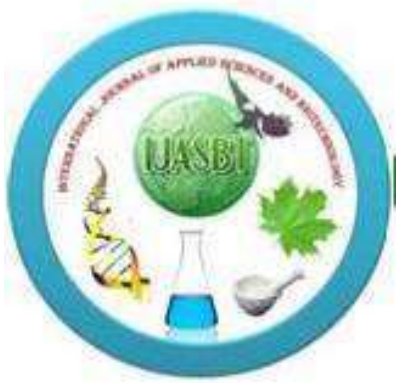 \\ International Journal of Applied Sciences and Biotechnology
}

\section{A Rapid Publishing Journal}

\section{ISSN 2091-2609}

\section{Indexing and Abstracting}

CrossRef, Google Scholar, Global Impact Factor, Genamics, Index Copernicus, Directory of Open Access Journals, WorldCat, Electronic Journals Library (EZB), Universitätsbibliothek Leipzig, Hamburg University, UTS (University of Technology, Sydney): Library, International Society of Universal Research in Sciences (EyeSource), Journal Seeker, WZB, Socolar, BioRes, Indian Science, Jadoun Science, JourInformatics, Journal Directory, JournalTOCs, Academic Journals Database, Journal Quality Evaluation Report, PDOAJ, Science Central, Journal Impact Factor, NewJour, Open Science Directory, Directory of Research Journals Indexing, Open Access Library, International Impact Factor Services, SciSeek, Cabell's Directories, Scientific Indexing Services, CiteFactor, UniSA Library, InfoBase Index, Infomine, Getinfo, Open Academic Journals Index, HINARI, etc.

\section{CODEN (Chemical Abstract Services, USA): IJASKD}

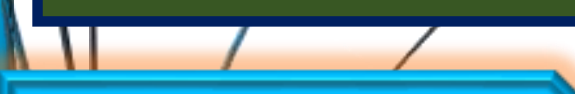

Vol-3(3) September, 2015

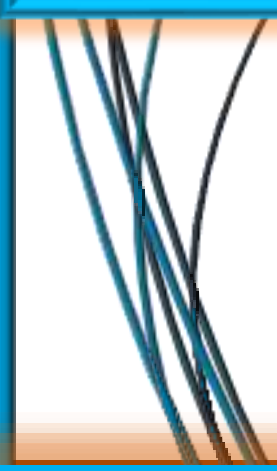

\section{Available online at:}

http://www.ijasbt.org

$\&$

http://www.nepjol.info/index.php/IJASBT/index

\section{Impact factor*: $\mathbf{1 . 4 2 2}$}

Scientific Journal Impact factor": $\mathbf{3 . 4 1 9}$

Index Copernicus Value: 6.02

SEM-Biotech

Publishing

*Impact factor is issued by Universal Impact Factor. Kindly note that this is not the IF of Journal Citation Report (JCR). \#Impact factor is issued by SJIF INNO SPACE; **Impact factor is issued by INFOBASE INDEX. 


\title{
EVALUATION OF QUALITY PROTEIN MAIZE AND DROUGHT TOLERANT MAIZE IN FAR WESTERN HILLS OF NEPAL
}

\author{
${ }^{1}$ Regional Agricultural Research Station, Bhagetada, Dipayal, Doti \\ ${ }^{2}$ National Maize Research Programme, Rampur, Chitwan, Nepal \\ Corresponding author email: hkprasai60@gmail.com
}

Hari Kumar Prasai ${ }^{1}$, Subarna Sharma ${ }^{1}$, Ujjawal Kumar Singh Kushwaha ${ }^{1}$ and Jiban Shrestha ${ }^{2}$

\begin{abstract}
The coordinated varietal trial of quality protein maize was carried out in research station of regional agricultural research station, Doti during 2011/12 and 2012/13. A total of fourteen entries including standard and local checks were included in the experiment of both years. Out of tested entries of the year 2011/12, S99TLYQ-A produced the highest grain yield (2814 kg/ha) followed by SO3TLYQ-AB-01 (2765 kg/ha) and SO3TLYQ-AB-02 (2293 kg/ha). MSTATC software was used in data analysis. Flowering days, plant height and grain yield due to genotypes was found significant at 1-5\% level. Amongst the tested entries include in the experiment of the year 2012/13, S99TLYQ-AB recorded the highest grain yield (6006 kg/ha) followed by SO3TLYQ-AB-01 (5409 kg/ha) and S99TLYQ-A (5330 kg/ha). There was significant difference in flowering days, plant height, ear height and grain yield due to genotypes at 1-5\% level. Combined analysis over year was also carried out. Genotypes SO3TLYQ-AB-01 (4087 kg/ha), S99TLYQ-A (4072 kg/ha) and S99TLYQ-AB (3750 kg/ha) identified as promising genotypes for lower hills and river basin agro-environment of far western hills. Similarly, experiment on selection of drought tolerance maize genotypes was also carried out at this research station during 2011/12 and 2012/13. Total 105 genotypes of maize were planted for selection of drought tolerance maize genotypes during 2011/12 and it was replicated twice. Quantitative and qualitative traits were recorded for screening against drought. Out of the genotypes included in the experiment, Manakamana-4 was found super variety in terms of grain yield (4561 kg/ha), leaf senescence (1) and leaf roll (1). Statistically, plant height, ear height, flowering days and leaf senescence due to genotypes were found significantly different. Total eight genotypes were selected for second year's drought tolerance genotypes selection experiment and were planted in three replications. Out of the eight genotypes included in the experiment, Upahar (6897 kg/ha), TLBRSO7F16 (6216 kg/ha) and BLSBSO7F12 (6215 kg/ha) were found superior in terms of grain yield.
\end{abstract}

Key words: genotypes; grain yield; kg/ha; drought; resistance; significant; traits.

\section{Introduction}

Maize comes in third position in cultivated area coverage after wheat and rice in far western hills of Nepal. Maize cultivation is a way of life for most farmers in the hills of Nepal. It is a traditional crop cultivated as food, feed and fodder on slopping Bari land (rainfed upland) in the hills. It is grown under rainfed conditions during the summer (April-August) as a single crop or relayed with millet later in the season.

The centre of origin of maize is the Mesoamerican region, probably in the Mexican highlands, from where it spread rapidly. Archaeological records and phylogenetic analysis suggest that domestication began at least 6,000 years ago (Piperno and Flannery 2001; Matsuoka et al., 2002). Maize spread around the world after European discovery of the Americas in the $15^{\text {th }}$ century, particularly in temperate zones (Paliwal 2000; Farnham et al., 2003).
Maize can be grown in a number of environments (Farnham et al., 2003) from $58^{\circ}$ North to $40^{\circ}$ South. Generally, tropical maize is grown between $30^{\circ}$ North and $30^{\circ}$ South, subtropical maize between 30 and $34^{\circ}$ both North or South, and temperate maize beyond $34^{\circ}$ latitudes. It can be grown in a range of altitudes from sea level up to 3,800 meters and with growing seasons between 42 and 400 days. This ability to grow in a wide range of environments is reflected in the high diversity of morphological and physiological traits (Edmeads, 2008).

Maize grain yields in the temperate developed world average 8.2 ton/ha, vs. $3.5 \mathrm{t} / \mathrm{ha}$ in tropical less developed countries. In both production environments drought is the most important abiotic stresses constraining and destabilizing maize grain production, and is one of several reasons for the differences between mean production levels of temperate vs. tropical regions. In both regions water deficits occur unpredictably throughout the season. Withinfield variability in soil texture and depth means that plant- 
available soil water also varies, and this can result in yield variation of up to 10 -fold in a relatively dry year. Since farmers usually plant a single variety in any given field, this implies a need for a good level of drought tolerance in the large majority of hybrids and varieties grown under rainfed conditions.

An investigation on chemical composition of QPM and normal maize was carried out by Martinez et al. (1996). It was reported that QPM contained higher amounts of protein, fat, dietary fibre and ash $(10.56,3.56$ and $1.72 \%$, respectively) when compared to normal maize (10.44, 2.66 and $1.28 \%$, respectively). Starch content was lower in QPM than normal maize (82.6 Vs 84.2\%). However, QPM showed better lysine content (42 $\mathrm{g} / \mathrm{kg}$ of protein) than normal maize (35 g/kg of protein). Similar higher lysine content of QPM varieties was reported by Ahenkora et al. (1999). A range 3.7 to $4.2 \mathrm{~g} / 100 \mathrm{~g}$ of protein was reported which was significantly higher than that of normal maize (2.6 to $3.1 \mathrm{~g} / 100 \mathrm{~g}$ protein). A comparative study on QPM cultivars and commercial maize varieties was conducted by Zarkadas et al. (2000). It was observed that QPM genotypes contained high levels of lysine (3.43 to $4.21 \mathrm{~g} / 100 \mathrm{~g}$ of protein) compared to commercial maize varieties which ranged from 2.9 to $3.1 \mathrm{~g} / 100 \mathrm{~g}$ of protein.

\section{Materials and Methods}

\section{Study site description}

Coordinated varietal trial of quality protein maize was carried out in research station of Regional Agricultural Research Station, Doti during 2011/12 and 2012/13. The experiments was located at altitude of $610 \mathrm{~m}$ above mean sea level on $29^{\circ} 15^{\prime}$ north latitude and $80^{\circ} 55^{\prime}$ east longitudes. The soil was light texture, low organic matter (1-2\%) and acidic in nature containing $\mathrm{pH} 6$.

\section{Experimental Design and Crop Husbandry}

Total fourteen entries including standard and local checks were included in the experiment of both years. Genotypes studied under this experiment were SO3TLYQ-AB-01, SO3TLYQ-AB-02, RampurSO3FQ02, S99TLYQ-AB, SOOTLYQ-AB, SOOTLYQ-B, SOISIYQ, Collorolozo SO2SIYQ, S99TLYQ-HG-AB, S99TLYQ-A, S99TLYQHG-B, SO2G29YQ, Rampur Composite and Farmers' local. Experiment was carried out in Randomized Complete Block design. Net Plot size for each entry was 9 Sq. m (3 m x 3 m) [4 rows of $3 \mathrm{~m}$ length]. Planting geometry was maintained as $75 \mathrm{~cm}$ x $25 \mathrm{~cm}$. Fertilizer was applied @ 120:60:40 NPK kg/ha with basal application@60:60:40 NPK kg/ha . Morphological and yield attributing data such as tasseling days, silking days, plant height, ear height and grain yield $(\mathrm{kg} / \mathrm{ha})$ were recorded.

Similarly, the experiment on selection of drought tolerance maize genotypes was also carried out at RARS, Doti during
2011/12 and 2012/13. Total 105 genotypes of maize were planted for selection of drought tolerance maize genotypes during 2011/12 and it was replicated twice. This experiment was also planted during 2012/13, but only eight genotypes which were selected from first year's (2011/12) experiment were planted with three replication. These selected genotypes includes TLBRSO7F16, Upahar, Manakamana4, RPOP-3, ACROSS 9331, BLSBSO7F10, BLSBSO7F12 and TLBRSO7F14. The experiment was conducted in RCBD and spacing of $75 \mathrm{~cm} \mathrm{x} 25 \mathrm{~cm}$ was maintained. Fertilizer was applied @ 120:60:40 NPK kg/ha with basal application@60:60:40 NPK kg/ha. Quantitative data such as tasseling days, silking days, plant height, ear height and grain yield $(\mathrm{kg} / \mathrm{ha}$ ) were recorded.. Besides this, for indirect selection to drought tolerance, qualitative data such as tassel size, leaf senescence and leaf rolling were also recorded in both the year.

\section{Data Analysis}

Analysis of variance for grain yield and other ancillary characters of maize were analyzed with MSTATC software. Treatments (variety) were compared using the "F-test" and any significant differences between treatments were compared by Least Significant Difference (LSD) at 5\% level of probability.

\section{Results and Discussion}

In coordinated varietal trial of quality protein maize; out of tested fourteen entries of the year 2011/12, S99TLYQ-A produced the highest grain yield $(2814 \mathrm{~kg} / \mathrm{ha})$ followed by SO3TLYQ-AB-01 (2765 kg/ha) and SO3TLYQ-AB-02 (2293 kg/ha). Statistically, the difference in flowering days, plant height and grain yield due to genotypes was found significant at $1-5 \%$ level (Table 1). Amongst the tested entries include in the experiment of the year 2012/13, S99TLYQ-AB recorded the highest grain yield (6006 $\mathrm{kg} / \mathrm{ha}$ ) followed by SO3TLYQ-AB-01 (5409 kg/ha) and S99TLYQ-A $(5330 \mathrm{~kg} / \mathrm{ha})$. Statistically significant difference was observed in flowering days, plant height, ear height and grain yield (Table 2).

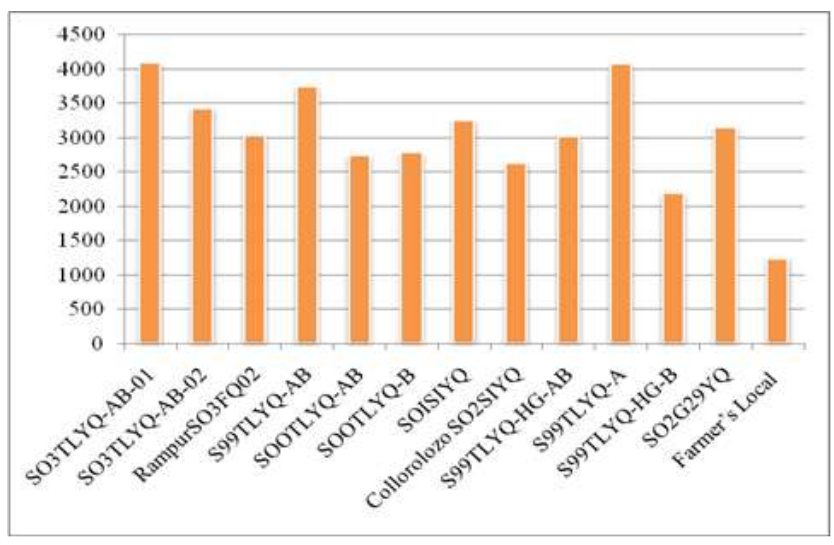

Fig. 1: Average Grain yield (kg/ha) of QPM Genotypes in 2011/12 and 2012/13 
Table 1: Grain yield and other ancillary characters of maize (QPM) during 2011/12

\begin{tabular}{|c|c|c|c|c|c|c|}
\hline \multirow{2}{*}{ SN } & \multirow[t]{2}{*}{ Treatment } & \multicolumn{2}{|c|}{ Flowering days } & \multirow{2}{*}{$\begin{array}{l}\text { Plant height } \\
\text { (cm) }\end{array}$} & \multirow{2}{*}{$\begin{array}{l}\text { Ear height } \\
\text { (cm) }\end{array}$} & \multirow{2}{*}{$\begin{array}{l}\text { Grain yield } \\
(\mathrm{kg} / \mathrm{ha})\end{array}$} \\
\hline & & Male & Female & & & \\
\hline 1 & SO3TLYQ-AB-01 & 56 & 60 & 223 & 119.3 & 2765 \\
\hline 2 & SO3TLYQ-AB-02 & 53.3 & 58 & 210 & 98.3 & 2294 \\
\hline 3 & RampurSO3FQ02 & 53 & 57.3 & 210.3 & 97.7 & 1267 \\
\hline 4 & S99TLYQ-AB & 55 & 58.7 & 202.7 & 101.7 & 1495 \\
\hline 5 & SOOTLYQ-AB & 54.7 & 58.3 & 216.7 & 102.7 & 1889 \\
\hline 6 & SOOTLYQ-B & 54 & 57.7 & 220 & 109 & 2148 \\
\hline 7 & SOISIYQ & 54 & 58.3 & 203.7 & 101.7 & 1369 \\
\hline 8 & Collorolozo SO2SIYQ & 52.7 & 57.3 & 165 & 67.7 & 1116 \\
\hline 9 & S99TLYQ-HG-AB & 53.7 & 57.7 & 209.7 & 101 & 1514 \\
\hline 10 & S99TLYQ-A & 53 & 56.3 & 235.7 & 119 & 2815 \\
\hline 11 & S99TLYQ-HG-B & 53.7 & 58 & 217.3 & 104.3 & 1504 \\
\hline 12 & SO2G29YQ & 47 & 50 & 208 & 83.3 & 1705 \\
\hline 13 & Rampur Composite & 50 & 54 & 236.7 & 125.7 & 1789 \\
\hline \multirow[t]{4}{*}{14} & Farmer's Local & 36.7 & 40 & 144.7 & 81.7 & 1031 \\
\hline & F test & $* *$ & $* *$ & $* *$ & NS & $*$ \\
\hline & $\mathrm{LSD}_{0.05}$ & 1.85 & 2.1 & 36.99 & - & 1120 \\
\hline & $\mathrm{CV} \%$ & 2.13 & 2.25 & 10.63 & 25.50 & 26.10 \\
\hline
\end{tabular}

Table 2: Grain yield and other ancillary characters of maize (QPM ) during 2012/13

\begin{tabular}{|c|c|c|c|c|c|c|}
\hline \multirow[t]{2}{*}{ SN } & \multirow[t]{2}{*}{ Treatment } & \multicolumn{2}{|c|}{ Flowering days } & \multirow{2}{*}{$\begin{array}{l}\text { Plant height } \\
\text { (cm) }\end{array}$} & \multirow{2}{*}{$\begin{array}{l}\text { Ear height } \\
\text { (cm) }\end{array}$} & \multirow{2}{*}{$\begin{array}{c}\text { Grain yield } \\
\text { (kg/ha) }\end{array}$} \\
\hline & & Male & Female & & & \\
\hline 1 & SO3TLYQ-A-01 & 53 & 55.3 & 230.3 & 94.7 & 5409 \\
\hline 2 & SO3TLYQ-AB-02 & 53 & 54.3 & 228.7 & 92.3 & 4564 \\
\hline 3 & RampurSO3FQ02 & 51.3 & 54.3 & 258.7 & 113.7 & 4786 \\
\hline 4 & S99TLYQ-AB & 50 & 53 & 259.7 & 117.3 & 6006 \\
\hline 5 & SOOTLYQ-AB & 53.7 & 55.7 & 251.3 & 104.3 & 3590 \\
\hline 6 & SOOTLYQ-B & 53 & 56 & 232 & 103.3 & 3422 \\
\hline 7 & SOISIYQ & 53 & 55.3 & 262.7 & 117.3 & 5137 \\
\hline 8 & Collorolozo SO2SIYQ & 52.3 & 54 & 251 & 118 & 4158 \\
\hline 9 & S99TLYQ-HG-AB & 53 & 55.7 & 240.3 & 102.7 & 4542 \\
\hline 10 & S99TLYQ-A & 50.7 & 53.7 & 233.7 & 101.3 & 5331 \\
\hline 11 & S99TLYQ-HG-B & 53.3 & 56 & 247.7 & 104.3 & 2897 \\
\hline 12 & SO2G29YQ & 44.7 & 48.3 & 235 & 95 & 4614 \\
\hline 13 & Poshilo Makai-1 & 54.3 & 56.3 & 219.3 & 91.7 & 3118 \\
\hline \multirow[t]{4}{*}{14} & Farmer's Local & 37 & 41 & 184.7 & 58 & 1662 \\
\hline & F-test & $* *$ & $* *$ & $*$ & $* *$ & $*$ \\
\hline & $\mathrm{LSD}_{0.05}$ & 2.24 & 2.95 & 32.5 & 17.76 & 2351.87 \\
\hline & $\mathrm{CV} \%$ & 2.62 & 3.29 & 8.13 & 10.48 & 33.12 \\
\hline
\end{tabular}

Table 3. Grain yield and other ancillary characters of maize (QPM) in combined analysis over year (2011/12 and 2012/13)

\begin{tabular}{|c|c|c|c|c|c|c|}
\hline \multirow[t]{2}{*}{ SN } & \multirow[t]{2}{*}{ Treatment } & \multicolumn{2}{|c|}{ Flowering days } & \multirow{2}{*}{$\begin{array}{l}\text { Plant height } \\
\text { (cm) }\end{array}$} & \multirow{2}{*}{$\begin{array}{l}\text { Ear height } \\
(\mathrm{cm})\end{array}$} & \multirow{2}{*}{$\begin{array}{c}\text { Grain yield } \\
(\mathrm{kg} / \mathrm{ha})\end{array}$} \\
\hline & & Male & Female & & & \\
\hline 1 & SO3TLYQ-AB-01 & 54.5 & 57.7 & 226.7 & 107.0 & 4087 \\
\hline 2 & SO3TLYQ-AB-02 & 53.2 & 56.2 & 219.3 & 95.3 & 3429 \\
\hline 3 & RampurSO3FQ02 & 52.2 & 55.8 & 234.5 & 105.7 & 3043 \\
\hline 4 & S99TLYQ-AB & 52.5 & 55.8 & 231.2 & 109.5 & 3751 \\
\hline 5 & SOOTLYQ-AB & 54.2 & 57.0 & 234.0 & 103.5 & 2740 \\
\hline 6 & SOOTLYQ-B & 53.5 & 56.8 & 226.0 & 106.2 & 2785 \\
\hline 7 & SOISIYQ & 53.5 & 56.8 & 233.0 & 109.5 & 3253 \\
\hline 8 & Collorolozo SO2SIYQ & 52.5 & 55.7 & 208.0 & 92.8 & 2637 \\
\hline 9 & S99TLYQ-HG-AB & 53.3 & 56.7 & 225.0 & 101.8 & 3028 \\
\hline 10 & S99TLYQ-A & 51.8 & 55.0 & 234.7 & 110.2 & 4073 \\
\hline 11 & S99TLYQ-HG-B & 53.5 & 57.0 & 232.5 & 104.3 & 2200 \\
\hline 12 & SO2G29YQ & 45.8 & 49.2 & 221.5 & 89.2 & 3159 \\
\hline \multirow[t]{5}{*}{13} & $\begin{array}{l}\text { Farmer's Local } \\
\text { F-test }\end{array}$ & 36.8 & 40.5 & 164.7 & 69.8 & 1246 \\
\hline & Factor A (Variety) & $* *$ & $* *$ & $* *$ & ns & $* *$ \\
\hline & Factor B (Year) & $* *$ & $* *$ & $* *$ & $* *$ & $* *$ \\
\hline & Fac A x Fac B & $* *$ & $*$ & $*$ & ns & ns \\
\hline & $\mathrm{CV} \%$ & 2.66 & 2.99 & 9.52 & 19.55 & 36.57 \\
\hline
\end{tabular}


Combined analysis over year was also carried out and genotypes SO3TLYQ-AB-01 (4087 kg/ha), S99TLYQ-A (4072 kg/ha) and S99TLYQ-AB (3750 kg/ha) were identified promising for lower hills and river basin agroenvironment of far western hills. Statistically, effect of treatment and year for grain yield was found significant at $1 \%$ level whereas interaction effect of treatment and year was found non-significant from combined analysis over year (Table 3 and Figure 1).

Similarly, out of the genotypes included in the first year of drought tolerance maize experiment (2011/12), Manakamana-4 was found super variety in terms of grain yield (4561 kg/ha), leaf senescence (1) and leaf roll (1). Out of 105 genotypes, only eight genotypes were selected for next year's drought tolerance genotypes selection experiment and data of only these selected eight genotypes have been presented in the following tables of the FY 2011/12. Statistically, difference in tested traits like plant height, ear height, flowering days and leaf senescence due to genotypes was found significant whereas difference in leaf rolling, tassel size and grain yield due to genotypes was found non-significant (Table 4 and Table 5).

Out of the eight genotypes included in experiment of the year 2012/13, Upahar (6897 kg/ha), TLBRSO7F16 (6216 $\mathrm{kg} / \mathrm{ha})$ and BLSBSO7F12 (6215 kg/ha) genotypes were found superior in terms of grain yield. Statistically, the difference in tested traits like plant height, ear height, leaf rolling, leaf senescence, tassel size and grain yield due to genotypes was found non-significant (Table 6 and Table 7).

Table 4: Quantitative traits of drought tolerance experiment of the year 2011/12

\begin{tabular}{|c|c|c|c|c|c|c|}
\hline \multirow[t]{2}{*}{ SN } & \multirow[t]{2}{*}{ Treatment } & \multirow{2}{*}{$\begin{array}{l}\text { Plant height } \\
(\mathrm{cm})\end{array}$} & \multirow{2}{*}{$\begin{array}{l}\text { Ear height } \\
(\mathrm{cm})\end{array}$} & \multicolumn{2}{|c|}{ Flowering days } & \multirow{2}{*}{$\begin{array}{l}\begin{array}{l}\text { Grain } \\
(\mathrm{kg} / \mathrm{ha})\end{array} \\
\end{array}$} \\
\hline & & & & Male & Female & \\
\hline 1 & TLBRSO7F16 & 255 & 126 & 54 & 56.5 & 3819 \\
\hline 2 & Upahar & 248 & 126 & 53 & 56.5 & 3672 \\
\hline 3 & Manakamana-4 & 276 & 127.5 & 53 & 56.5 & 4561 \\
\hline 4 & RPOP-3 & 249 & 117 & 54.5 & 58 & 2686 \\
\hline 5 & ACROSS 9331 & 234.5 & 120 & 51 & 55.5 & 3469 \\
\hline 6 & BLSBSO7F10 & 242.5 & 109.5 & 52.5 & 57.5 & 2168 \\
\hline 7 & BLSBSO7F12 & 254 & 124.5 & 52.5 & 55.5 & 2834 \\
\hline \multirow[t]{4}{*}{8} & TLBRSO7F14 & 257.5 & 121.5 & 50 & 53.5 & 4168 \\
\hline & F-test & $* *$ & $* *$ & $* *$ & $* *$ & NS \\
\hline & $\mathrm{LSD}_{0.05}$ & 53.56 & 33.94 & 4.2 & 5.89 & - \\
\hline & $\mathrm{CV} \%$ & 11.58 & 16.57 & 3.99 & 5.22 & 34.02 \\
\hline
\end{tabular}

Table 5: Qualitative traits of drought tolerant experiment 2011/12

\begin{tabular}{llllc}
\hline SN & Treatment & $\begin{array}{c}\text { Leaf rolling } \\
(\mathbf{1 - 5})\end{array}$ & $\begin{array}{c}\text { Leaf senescence } \\
(\mathbf{1 - 5})\end{array}$ & $\begin{array}{c}\text { Tassel size } \\
(\mathbf{1 - 5})\end{array}$ \\
\hline 1 & TLBRSO7F16 & 1.5 & 2.0 & 1.0 \\
2 & Upahar & 2.0 & 2.0 & 1.5 \\
3 & Manakamana-4 & 1.0 & 1.0 & 1.0 \\
4 & RPOP-3 & 1.5 & 2.0 & 2.0 \\
5 & ACROSS 9331 & 2.0 & 2.0 & 2.5 \\
6 & BLSBSO7F10 & 1.0 & 1.5 & 1.5 \\
7 & BLSBSO7F12 & 1.5 & 1.5 & 2. \\
8 & TLBRSO7F14 & 2.0 & 2.0 & 1 \\
& F-test & $\mathrm{ns}$ & $*$ & $\mathrm{~ns}$ \\
& LSD 0.05 & 30.62 & 0.89 & 30.39 \\
& CV\% & 29.85 & \\
\hline
\end{tabular}

Table 6: Quantitative traits of drought tolerance experiment of the year 2012/13

\begin{tabular}{|c|c|c|c|c|c|c|}
\hline \multirow[t]{2}{*}{ SN } & \multirow[t]{2}{*}{ Treatment } & \multirow{2}{*}{$\begin{array}{l}\text { Plant height } \\
(\mathrm{cm})\end{array}$} & \multirow{2}{*}{$\begin{array}{l}\text { Ear height } \\
\text { (cm) }\end{array}$} & \multicolumn{2}{|c|}{ Flowering days } & \multirow{2}{*}{$\begin{array}{l}\text { Grain } \\
(\mathrm{kg} / \mathrm{ha})\end{array}$} \\
\hline & & & & Male & Female & \\
\hline 1 & TLBRSO7F16 & 261.3 & 127.7 & 51.7 & 53.3 & 6262 \\
\hline 2 & Upahar & 267.3 & 138.3 & 46.3 & 50.3 & 6898 \\
\hline 3 & Manakamana-4 & 274.6 & 124.3 & 52.0 & 53.7 & 5626 \\
\hline 4 & RPOP-3 & 249.0 & 128.3 & 47.3 & 51.0 & 5458 \\
\hline 5 & ACROSS 9331 & 255.7 & 119.0 & 45.0 & 49.0 & 5175 \\
\hline 6 & BLSBSO7F10 & 239.3 & 112.3 & 46.0 & 48.7 & 4542 \\
\hline 7 & BLSBSO7F12 & 253.0 & 119.0 & 47.7 & 51.3 & 6215 \\
\hline \multirow[t]{4}{*}{8} & TLBRSO7F14 & 277.3 & 135.0 & 48.0 & 52.3 & 5596 \\
\hline & F-test & ns & ns & $* *$ & $* *$ & ns \\
\hline & $\mathrm{LSD}_{0.05}$ & & & 2.37 & 2.28 & \\
\hline & CV\% & 6.85 & 10.94 & 2.82 & 2.54 & 13.64 \\
\hline
\end{tabular}


Table 7: Qualitative traits of drought tolerance experiment of the year 2012/13

\begin{tabular}{lllcc}
\hline SN & Treatment & $\begin{array}{c}\text { Leaf rolling } \\
(\mathbf{1 - 5})\end{array}$ & $\begin{array}{c}\text { Leaf senescence } \\
(\mathbf{1 - 5})\end{array}$ & Tassel size (1-5) \\
\hline 1 & TLBRSO7F16 & 3.67 & 5.00 & 3.33 \\
2 & Upahar & 3.33 & 4.67 & 2.67 \\
3 & Manakamana-4 & 3.33 & 5.00 & 3.00 \\
4 & RPOP-3 & 3.33 & 5.00 & 3.33 \\
5 & ACROSS 9331 & 3.67 & 5.00 & 3.67 \\
6 & BLSBSO7F10 & 3.33 & 5.33 & 3.33 \\
7 & BLSBSO7F12 & 3.33 & 5.00 & 4.00 \\
8 & TLBRSO7F14 & 4.00 & 5.00 & 3.67 \\
& F-test & $\mathrm{ns}$ & $\mathrm{ns}$ & \\
& LSD 0.05 & 1.14 & & \\
& CV\% & 18.57 & 5.56 & 15.33 \\
\hline
\end{tabular}

Tassel size: $1=$ few branches and small tassel, 5= many branches and large tassel.

Senescence: $1=10 \%$ dead leaf area, $10=100 \%$ dead leaf area.

Leaf rolling: $1=$ Unrolled and turgid, $5=$ Leaf totally rolled like an onion.

\section{Conclusion}

Selection of high yielding genotypes for a particular location is the most important task in varietal development program. The QPM genotypes namely SO3TLYQ-AB-01, S99TLYQ-A and S99TLYQ-AB were identified as promising genotypes for lower hills and river basin agroenvironment of far western hills. Similarly, maize genotypes UPAHAR, TLBRSO7F16 and BLSBSO7F12 were identified as better drought tolerant genotypes. These experiments need to be continued for one more year for final conclusion.

\section{Acknowledgement}

Authors are thankful to Executive Director and Director of Crops and Horticulture Research, NARC for their constructive suggestions and moral support in implementing the experiment. Authors also express their sincere thanks to the concerned scientist of NMRP, Rampur for providing genetic materials and technical guidance. The technical staffs of RARS, Doti deserve special thanks for their untiring efforts for implementing research in the field.

\section{References}

Ahenkora K., Twumasi AS, Sallah PYK and Obeng-Antwi K. (1999) Protein nutritional quality and consumer acceptability of tropical Ghanaian quality protein maize. Food and Nutrition Bulletin, 20(3): 354-359.

Edmeads Greg O (2008) Drought tolerance in maize: an emerging reality. Companion Document to Executive Summary ISAAA Briefs 39-2008.
Farnham DE, Benson GO and Pearce RB (2003) Corn perspective and culture. Chapter 1. In: PJ White, LA Johnson, eds. Corn: chemistry and technology, Edition ${ }^{2}$ nd. American Association of Cerial Chemicals, Inc. St. Paul, Minesota, USA. 1-33.

Martinez BF, Sevilla PE and Bjarnason N (1996) Wet milling comparison of quality protein maize and normal maize. Journal of Science Food and Agriculture, 71: 156-162. DOI: 10.1002/(SICI)1097-0010(199606)71:2<156::AIDJSFA561>3.0.CO;2-V

Matsuoka Y, Vigouroux Y, Goodman MM, Sanchez G J, Buckler E., Doebley J (2002) A single domestication for maize shown by multilocus microsatellite genotyping. Proceedings of the National Academy of Sciences 99: 6080-6084. DOI: 10.1073/pnas.052125199

Paliwal RL (2000) Origin, Evolution and Spread of Maize. In: RL Paliwal, G Granados, HR Lafitte, AD Vlollc, eds. Tropical Maize: Improvement and Production Food and Agriculture Organization of the United Nations Rome. pp 5-11.

Piperno DR and Flannery KV (2001) The earliest archaeological maize (Zea mays L.) from highland Mexico: New accelerator mass spectrometry dates and their implications. Proceedings of the National Academy of Sciences 98: 2101-2103. DOI: 10.1073/pnas.98.4.2101

Zarkadas CG, Hamilton RI, Yu-Zi RAN, Choi VK., Khanizadem S, Rose NGW and Pattison PL (2000) Assessment of the protein quality of 15 new northern adapted cultivars of quality protein maize using amino acid analysis. Journal of Agricultural and Food Chemistry, 48(11): 5351-5361. DOI: $10.1021 /$ jf000374b 